\title{
Determination of Genetic Relationship among Wilt Resistant and Susceptible Varieties of Chickpea by RAPD Markers
}

\author{
D.H. Sarnobat*, C.D. Deokar and K.S. Raghuwanshi \\ Department of Plant Pathology and Agriculture Microbiology, MPKV, Rahuri, India \\ *Corresponding author:
}

\section{Keywords}

Chickpea, RAPD,

Genetic diversity,

Fusarium wilt

Article Info

Accepted:

10 January 2019

Available Online:

10 February 2019

\section{A B S T R A C T}

The molecular evaluation of twelve chickpea (Cicer arietinum L.) varieties (screened for their resistance to fusarium wilt) at the Department of Plant Pathology and Agriculture Microbiology in 2014-15 was conducted to assess the genetic diversity and relationship of chickpea genotypes using RAPD. Twenty five primers of RAPD were used of which 15 primers gave amplification products. A total 349 amplicons were obtained of which 331 amplicons were polymorphic with $93.64 \%$ level of polymorphism was observed. Cluster analysis by RAPD and ISSR markers revealed clear distinct diversity between genotypes. The similarity coefficient ranged from 0.64 to 0.92 showed high genetic variability. Digvijay revealed the highest dissimilarity comparing with the other varieties. JG 62 and Vikas showed more similarity than others varieties. The results showed that RAPD analysis for diversity can provide practical information for the management of genetic resources in chickpea breeding program.

\section{Introduction}

Chickpea (Cicer arietinum L.), as the second most important cool season food legume in the world after dry beans and peas (FAO, 2006), is a diploid, with $2 \mathrm{n}=2 \mathrm{x}=16$ (Aru Muganathan et al., 1991) and has a genome size of approximately $931 \mathrm{Mbp}$. Moreover, chickpea pod covers and seed coats can also be used as fodder. In grain legumes, proteins are an important seed component and are responsible for their relevant nutritional a socioeconomic importance. The chickpea seed is a good source of carbohydrates and proteins, which together constitute $80 \%$ of the total dry seed weight (Talebi et al., 2008). Two main types of chickpea cultivars are grown globally kabuli and desi, representing two diverse gene pools. The knowledge of genetic diversity is a useful tool in gene bank management and breeding experiments like tagging of germplasm, identification and/or elimination of duplicates in the gene stock and establishment of core collections Genetic diversity among the parents is a rerequisite to improve the chances of selecting better segregates for various characters (Dwevedi $e t$ al., 2009). Differences between genotypes with regard to susceptible and resistant reaction to the wilt disease and molecular 
characteristics are either indirect or direct representations of differences at the DNA level and are therefore expected to provide information about genetic relationships. The assessment of genetic diversity is important not only for crop improvement but also for efficient management and conservation of germplasm resources. For this purpose 6 wilt resistant and 6 wilt susceptible varieties of chickpea were analyzed by using random amplified polymorphic DNA (RAPD) markers. Polymerase chain reaction (PCR) method, using RAPD primers, has been widely utilized in the last 20 years. DNA markers have proved valuable in crop breeding, especially in studies on genetic diversity and gene mapping.

The RAPD technique, based on the PCR, is one of the most commonly used molecular markers. RAPD markers are amplification products of anonymous DNA sequence using single, short and arbitrary oligonucleotide primer; thus, they do not require prior knowledge of DNA sequence.

Low expense efficiency in developing a large number of DNA markers in a short time and requirement for less sophisticated equipment has made the RAPD technique valuable (Bardakci, 2001). RAPD identification techniques can be used at any stage of plant development and they are not affected by environment factors (Lisek et al., 2006). The reproducibility of the RAPD techniques can be influenced by variable factor, such as concentration of $\mathrm{MgCl} 2$, DNA template; DNA polymerase (Iqbal et al., 2002); number of primer; primer sequence; number of PCR cycles (Nkongolo et al., 2002) and annealing temperature (Schiliro et al., 2001).

The aim of this study is to evaluate the genetic diversity of wilt resistant and susceptible chickpea varieties by RAPD markers.

\section{Materials and Methods}

\section{Plant material}

Six wilt resistant varieties of chickpea viz. WR 315, Digvijay, Vishal, Virat, Vihar, Vijay and Six wilt susceptible varieties of chickpea viz Vikas, Vishwas, Phule G-12, ILC 'O', L550, JG 62 were used in this study (Table 2).

All varieties were obtained from All India Pulses Improvement Project, MPKV, Rahuri. Healthy seeds with identical dimensions were selected by visual observation.

\section{Genomic DNA extraction and purification}

Seeds were planted in a pot for three weeks at the Dept. of Plant Pathology and Agriculture Microbiology. Watering was done once a day and, after three weeks, healthy leaves were harvested. Total DNA was extracted from three weeks young chickpea leaves following the CTAB procedure (Cingilli et al., 2005).

\section{RAPD analysis}

Twenty five primers were used in this study, only fiften primers gave the products (Table $1)$.

The reaction mixture $(25 \mu \mathrm{l})$ contained $10 \times$ assay buffer, $2.5 \mathrm{mM} \mathrm{MgCl2}, 400 \mu \mathrm{M}$ dNTP's (Fermantas), 5 pmoles of primer, 100 ng template DNA and $1 \mathrm{U}$ of Taq DNA Polymerase (Fermantas). Amplification was carried out in a thermo-cycler (Master cycler) for 40 cycles, each consisting of a denaturation step at $94{ }^{\circ} \mathrm{C}$ for $1 \mathrm{~min}$, annealing at 32,34 and $36{ }^{\circ} \mathrm{C}$ for 50 second and an extension step at $72{ }^{\circ} \mathrm{C}$ for $2 \mathrm{~min}$. An initial denaturation step at $94{ }^{\circ} \mathrm{C}$ for $5 \mathrm{~min}$, and a final synthesis step of $6 \mathrm{~min}$ at $72{ }^{\circ} \mathrm{C}$ were also included. Amplification products were separated on $1.5 \%$ agarose gel in $1 \mathrm{X}$ TAE (Tris base, acetic acid and EDTA) buffer 


\section{Data analysis}

Following Lynch and Milligan (Lynch et al., 1994) assumptions, each amplified product was treated as an independent locus and assigned numbers in order of decreasing molecular weight. DNA fragment profiles representing a consensus of two independent replicates were scored in a binary fission with ' 0 ' indicating the absence and ' 1 ' indicating presence of band. Using the binary data, a similarity matrix was constructed using the Jaccard coefficient (Jaccard, 1908), which was further subjected to clustering analysis and a dendrogram was generated. A cophenetic matrix was constructed using the matrix that was used to generate the clusters. A correlation between the cophenetic matrix and the similarity matrix was determined by using SPSS version 18 (Masumbuko et al., 2003).

\section{Results and Discussion}

The Twelve Varieties of chickpea viz. WR 315, Digvijay, Vishal, Virat, Vihar, Vijay, Vikas, Vishwas, Phule G-12, ILC 'O', L550 and JG 62 were screened in wilt sick plot for confirmation of resistant and susceptible for wilt. The results are shown in table 2 .

RAPD analysis revealed a good polymorphism among chickpea varieties. (Figure 2) Twenty five random primers of RAPD were used in this study. From RAPD data $6.36 \%$ of common bands and 93.64 (Table 3) of polymorphic bands were observed among chickpea varieties.

The primer UBC 701 gave rise to maximum bands (43) and UBC 709 showed the least number of bands (7) (Figure 2). Cluster analysis was carried out depending on the results of RAPD analysis using the SPSS analysis to find the diversity among the given varieties of chickpea as shown in the dendrogram (Figure 1). At Jaccard dissimilarity of distance Phule G 12 and L 550 showed more similarity than others varieties. These two varieties are susceptible to wilt. The resistant genotypes Vishal, Virat and WR 315 are grouped into one cluster while Vijay in another cluster. Digvijay showed more dissimilarity distance with the rest of the varieties.

Vijay and JG 62 showed more similarity and groped into one cluster though they have different in reaction to fusarium wilt. The similarity matrix varied from 0.64 to 0.92 in chickpea varieties. The highest value of similarity matrix was registered by phule $\mathrm{G}$ 12 and L 550 while the lowest value of similarity matrix was recorded by WR 315 and Digvijay (Table 4).

In this investigation, RAPD markers showed a high level of polymorphism and a high number of clearly amplified bands. The data reported in this study is in agreement with that obtained by other researchers. Extensive DNA polymorphism has been reported using RAPD markers in several other crops (Iruela et al., 2002; Hou et al., 2005).

The RAPD based dendrogram of chickpea genotypes displayed the genetic relationships between these accessions, which accorded with previous studies on chickpea (Ahmad et al., 1992; Tayyar et al., 1996 and Iruela et al., 2002). Although the Cicer species are predominantly selfpollinating, more variation was observed among them.

The reason for this genetic variation could be that the specific accessions were heterozygous at some marker loci. Similar observations were reported in pea, lentil (Simon et al., 1997), and chickpea (Moussa et al., 1996; Sant et al., 1999). Iruela et al., 2002) showed that RAPD markers successfully identified genetic variation in Cicer. 
Table.1 Sequences and Annealing temperature $\left({ }^{\circ} \mathrm{C}\right)$ of random primers used for RAPD Analysis

\begin{tabular}{|c|c|c|c|}
\hline Sr.No & Primer Screened & Sequence & Annealing temp. \\
\hline 1 & UBC701 & CCC ACA ACC C & $34^{0} \mathrm{C}$ \\
\hline 2 & UBC702 & GGG AGA AGG G & $34^{0} \mathrm{C}$ \\
\hline 3 & UBC703 & CCA ACC ACC C & $34^{0} \mathrm{C}$ \\
\hline 4 & UBC706 & GGT GGT TGG G & $34^{0} \mathrm{C}$ \\
\hline 5 & UBC709. & ССТ ССТ СCC T & $34^{0} \mathrm{C}$ \\
\hline 6 & UBC711 & ССC ТCТ СCC T & $34^{0} \mathrm{C}$ \\
\hline 7 & UBC717 & CCCACACCCA & $34^{0} \mathrm{C}$ \\
\hline 8 & UBC729 & CCC AAC CCA C & $34^{0} \mathrm{C}$ \\
\hline 9 & UBC751 & CCC ACC ACA C & $34^{0} \mathrm{C}$ \\
\hline 10 & UBC763 & CAC ACC ACC C & $34^{0} \mathrm{C}$ \\
\hline 11 & UBC764 & CTC TCC TCC C & $34^{0} \mathrm{C}$ \\
\hline 12 & UBC771 & СССТССТССС & $36^{0} \mathrm{C}$ \\
\hline 13 & UBC778 & CCA CAC CAC A & $32^{0} \mathrm{C}$ \\
\hline 14 & UBC783 & GGT GGG TTG T & $32^{0} \mathrm{C}$ \\
\hline 15 & UBC790 & GGA AGT CGC C & $34^{0} \mathrm{C}$ \\
\hline 16 & UBC 1-4 & CCTGGGTTCC & $34^{0} \mathrm{C}$ \\
\hline 17 & UBC 1-19 & GCCCGGTTTA & $32^{0} \mathrm{C}$ \\
\hline 18 & UBC $1-23$ & CCCGCCTTCC & $36^{0} \mathrm{C}$ \\
\hline 19 & UBC $1-28$ & CCGGCCTTAA & $32^{0} \mathrm{C}$ \\
\hline 20 & UBC $1-29$ & CCGGCCTTAC & $34^{0} \mathrm{C}$ \\
\hline 21 & UBC $1-30$ & CCGGCCTTAG & $34^{0} \mathrm{C}$ \\
\hline 22 & UBC 1-34 & CCGGCCCCAA & $36^{0} \mathrm{C}$ \\
\hline 23 & UBC $1-70$ & GGGCACGCGA & $36^{0} \mathrm{C}$ \\
\hline 24 & OPA 05 & AGGGGTCTTG & $32^{0} \mathrm{C}$ \\
\hline 25 & OPA 07 & GAAACGGGTG & $32^{0} \mathrm{C}$ \\
\hline
\end{tabular}

Table.2 Confirmation of resistance against wilt in chickpea genotypes under wilt sick soil

\begin{tabular}{|c|c|c|l|}
\hline Sr.No. & Name of genotypes & $\begin{array}{c}\text { Wilting } \\
\mathbf{\%}\end{array}$ & Reaction \\
\hline $\mathbf{1}$ & WR 315 & 0 & Immune \\
\hline $\mathbf{2}$ & Digvijay & 2.71 & Resistant \\
\hline $\mathbf{3}$ & Vishal & 3.84 & Resistant \\
\hline $\mathbf{4}$ & Virat & 5.28 & Resistant \\
\hline $\mathbf{5}$ & Vihar & 8.72 & Resistant \\
\hline $\mathbf{6}$ & Vijay & 6.18 & Resistant \\
\hline $\mathbf{7}$ & Vikas & 30 & Susceptible \\
\hline $\mathbf{8}$ & Vishwas & 42.6 & Highly Susceptible \\
\hline $\mathbf{9}$ & Phule G-12 & 54.22 & Highly Susceptible \\
\hline $\mathbf{1 0}$ & ILC 'O' & 81.75 & Highly Susceptible \\
\hline $\mathbf{1 1}$ & L550 & 83.30 & Highly Susceptible \\
\hline $\mathbf{1 2}$ & JG 62 & 100 & Highly susceptible \\
\hline
\end{tabular}


Table.3 Percent polymorphism observed in RAPD Primers

\begin{tabular}{|l|l|c|c|c|c|}
\hline $\begin{array}{l}\text { Sr. } \\
\text { No. }\end{array}$ & Primers & $\begin{array}{c}\text { Total No. } \\
\text { of Bands }\end{array}$ & $\begin{array}{c}\text { Polymorphic } \\
\text { Bands }\end{array}$ & $\begin{array}{c}\text { Monomorphic } \\
\text { Bands }\end{array}$ & $\begin{array}{c}\text { Percent } \\
\text { Polymorphism }\end{array}$ \\
\hline $\mathbf{1}$ & OPA 05 & 28 & 26 & 2 & 92.75 \\
\hline $\mathbf{2}$ & UBC 1-4 & 42 & 42 & 0 & 100 \\
\hline $\mathbf{3}$ & UBC 1-19 & 39 & 39 & 0 & 100 \\
\hline $\mathbf{4}$ & UBC 1-29 & 24 & 22 & 2 & 91.66 \\
\hline $\mathbf{5}$ & UBC 1-70 & 19 & 18 & 1 & 94.73 \\
\hline $\mathbf{6}$ & UBC 702 & 16 & 16 & 0 & 100 \\
\hline $\mathbf{7}$ & UBC 1-28 & 24 & 23 & 1 & 95.83 \\
\hline $\mathbf{8}$ & UBC 1-23 & 13 & 10 & 3 & 76.92 \\
\hline $\mathbf{9}$ & UBC 1-30 & 14 & 11 & 3 & 96.30 \\
\hline $\mathbf{1 0}$ & UBC 1-34 & 27 & 26 & 1 & 95.35 \\
\hline $\mathbf{1 1}$ & UBC 701 & 43 & 41 & 2 & 93.33 \\
\hline $\mathbf{1 2}$ & UBC 703 & 15 & 14 & 1 & 93.75 \\
\hline $\mathbf{1 3}$ & UBC 706 & 16 & 15 & 1 & 95.45 \\
\hline $\mathbf{1 4}$ & UBC 778 & 22 & 21 & 1 & 100 \\
\hline $\mathbf{1 5}$ & UBC 709 & 7 & 7 & 0 & $\mathbf{9 3 . 6 4 \% ( A v g . )}$ \\
\hline & & $\mathbf{3 4 9}$ & $\mathbf{3 3 1}$ & $\mathbf{1 8}$ & \\
\hline
\end{tabular}


Table.4 Jaccard similarity coefficient showing the relationship among chickpea varieties based on RAPD data

\begin{tabular}{|c|c|c|c|c|c|c|c|c|c|c|c|c|}
\hline & WR 315 & Digvijay & Vishal & Virat & Vihar & Vijay & JG-62 & Vikas & Vishwas & PhuleG12 & ILC'O & L550 \\
\hline WR 315 & 1 & & & & & & & & & & & \\
\hline Digvijay & 0.64 & 1 & & & & & & & & & & \\
\hline Vishal & 0.807 & 0.76 & 1 & & & & & & & & & \\
\hline Virat & 0.821 & 0.74 & 0.892 & 1 & & & & & & & & \\
\hline Vihar & 0.793 & 0.714 & 0.758 & 0.806 & 1 & & & & & & & \\
\hline Vijay & 0.779 & 0.701 & 0.813 & 0.825 & 0.861 & 1 & & & & & & \\
\hline JG-62 & 0.806 & 0.8 & 0.774 & 0.818 & 0.882 & 0.898 & 1 & & & & & \\
\hline Vikas & 0.779 & 0.842 & 0.779 & 0.793 & 0.8 & 0.878 & 0.898 & 1 & & & & \\
\hline Vishwas & 0.784 & 0.816 & 0.862 & 0.836 & 0.771 & 0.793 & 0.819 & 0.793 & 1 & & & \\
\hline PhuleG12 & 0.880 & 0.72 & 0.88 & 0.905 & 0.8 & 0.862 & 0.833 & 0.827 & 0.84 & 1 & & \\
\hline ILC'O' & 0.777 & 0.692 & 0.814 & 0.827 & 0.8 & 0.819 & 0.843 & 0.754 & 0.754 & 0.807 & 1 & \\
\hline L550 & 0.827 & 0.714 & 0.896 & 0.903 & 0.843 & 0.892 & 0.882 & 0.83 & 0.877 & 0.928 & 0.866 & 1 \\
\hline
\end{tabular}

Fig.1 Dendrogram of chickpea varieties showing the genetic similarity based on RAPD data by using cluster analysis

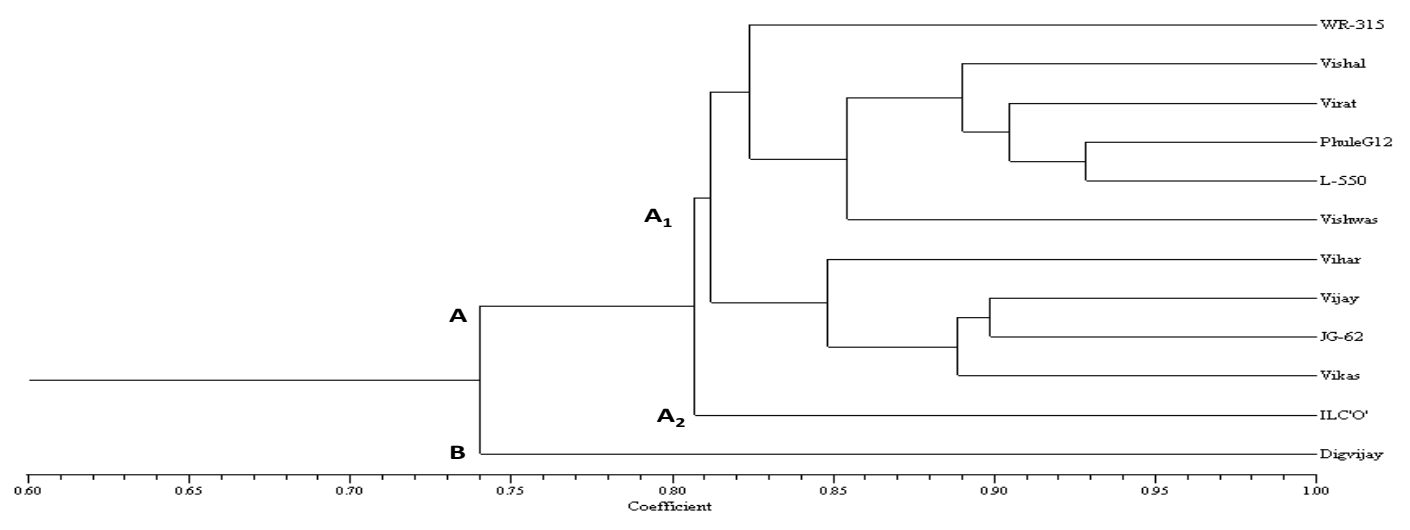


Fig.2

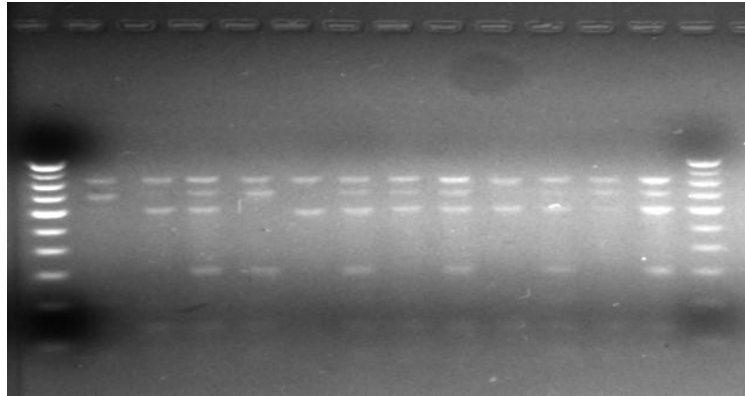

Primer OPA 05

Figure 2 - Agarose gel (1.5\%) showing the amplified product using RAPD primers, OPA 05 , Primer UBC 701, Primer UBC 709 and Primer UBC 703

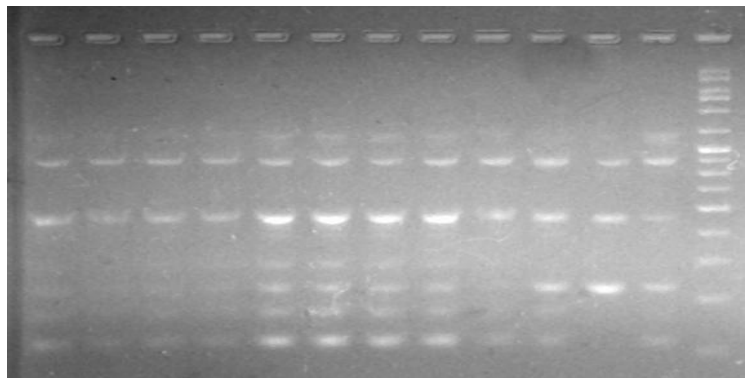

Primer UBC 701

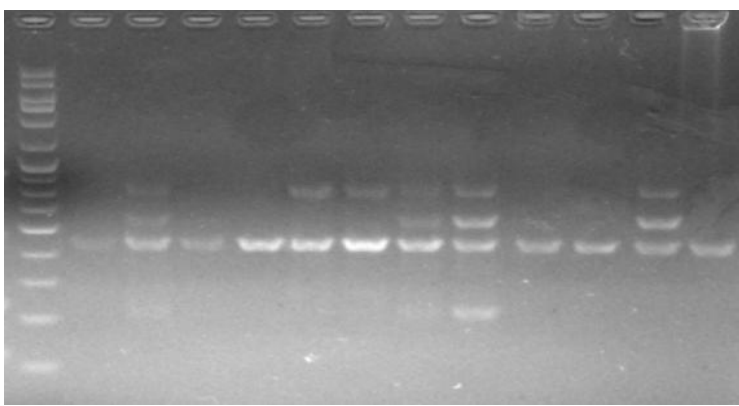

Primer UBC 703

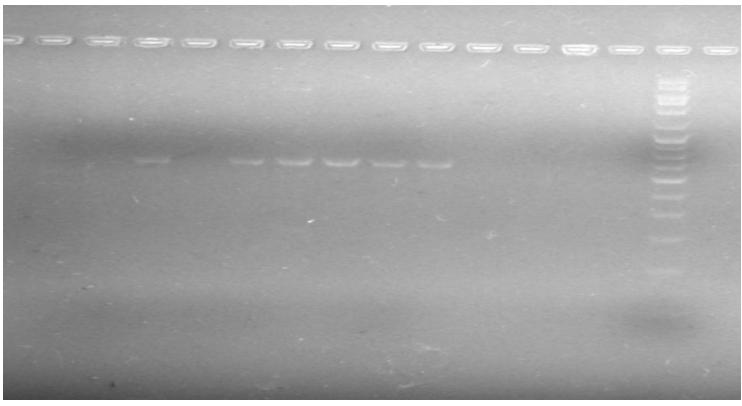

Primer UBC 709 
This observation was consistent with the study of Simon and Muehlbauer (1997), who detected variation within single $C$. reticulatum accession (PI 489777), used to generate an interspecific mapping population. Our results are in accordance with Iruela et al., (2002). Iruela reported the genetic diversity among $C$. arietinum varieties using RAPD. Shan et al., (2005) showed that a natural hybrid could be useful for bridging crosses to introduce genes to chickpea from incompatible species given that $C$.reticulatum was the wild progenitor of chickpea.

Further, large amount of genetic variation which exists between chickpea genotypes can be used efficiently for gene tagging and genome mapping of crosses to introgression the favorable traits such as high yield potential, disease resistance into the cultivated genotypes. Thus, RAPD markers were good indicators of morphological divergence.

In conclusion, the present investigation demonstrates the potential of RAPD fingerprinting in detecting polymorphism among chickpea varieties. Varieties Digvijay showed the highest dissimilarity comparing to others varieties. Genetic information obtained from RAPD markers can be used in discriminating chickpea varieties and can complement the genetic information generated from the morphological traits. Further, the genetic variation which exists between chickpea varieties can be used efficiently in plant breeding.

\section{References}

Ahmad F and Slinkard AE. 1992. Genetic relationships in the genus Cicer L. as revealed by olyacrylamide gel electrophoresis of seed storage proteins. Theor. Appl. Genet. 84: 688-92.

Arumuganathan K and Earle ED. 1991. Nuclear DNA content of some important Plant species. Plant. Ml. Biol. Reptr. 9: 208-218.

Bardakci F. 2001. Random amplified polymorphic DNA (RAPD) markers. Turk. J. Biol. 25:185-196.

Cingilli H and Akin A. 2005. High Quality DNA Isolation Method for Chickpea Genotypes. Turk. J. Biol., 29: 1-5

Dwevedi KK and Gaibriyal M. 2009. Assessment of genetic diversity of cultivated chickpea (Cicer arietinum L.) Asian J. Agri. Sci.1(1): 7-8.

Hou YC, Yan ZH, Wei YM and Zheng YL. 2005. Genetic diversity in barley from west china based on RAPD and ISSR analysis. Barley Genet. Newl. 35: 9-22.

Iqbal A, Khan AS, Khan IA, Awan FS, Ahmad A and Khan AA. 2002. Study of genetic divergence among wheat genotypes through random amplified polymorphic DNA. Gene Mol. Res., 6(3): 476-481.

Iruela M, Rubio J, Cubero JI,GilJ and MillánT. 2002. Phylogenetic analysis in the genus Cicer and cultivated chickpea using RAPD and ISSR markers. Theor. Appl. Genet.104: 643-651.

Jaccard P. 1908. Nouvells recherches sur la distribution florale. Bull. Soc. Vaud. Sci. Nat.44: 223-270.

Lisek A, Korbin M and Rozpara E. 2006. Using simple generation RAPD Markers to distinguishing between sweet cherry (Prunus avium L.) cultivars. J. Fruit Ornam. Plant Res. 14: 53-59.

Lynch M and Milligan BG. 1994. Analysis of population genetic structure with RAPD markers. Mol. Ecol., 3: 91-99.

Masumbuko LI, Bryngelssson T, Mneney E and Salomon B. 2003. Genetic diversity in Tanzanian arabica coffee using random amplified polymorphic DNA (RAPD) markers. Hereditas. 139: 5663.

Moussa EH, Millan T, Gil J and Cubero JI. 
1996. Variability and genome length estimation in chickpea (Cicer arietinum L.) revealed by RAPD analysis. J. Genet. Breed. 51: 83-85.

Nkongolo KK, Michael P and Gratton WS. 2002. Cloning and characterization of RAPD markers inferring genetic relationships among pine species. Genome, 45: 51 -58.

Sant VJ, Patankar AG, Sarode ND, Mhase LB, Sainani MN, Deshmukh RB, Ranjekar PK and Gupta VS. 1999. Potential of DNA markers in detecting divergence and in analyzing heterosis in Indian elite chickpea cultivars. Theor. Appl. Genet. 98: 1217-1225.

Schiliro A, Predier S and Bertaccini A. 2001. Use of random amplified Polymorphic DNA analysis to detect genetic variation in Pyrus Species. Plant Mol. Biol. Reptr. 19: 217.

Shan F, Clarke HC, Plummer JA, Yan Gand Siddique KH. 2005. Geographical patterns of genetic variation in the world collections of wild annual Cicer characterized by amplified fragment length polymorphism. Theor. Appl. Genet.110: 381-391.

Simon CJ and Muehlbauer FJ. 1997. Construction of chickpea linkage map and its comparison with the maps of pea and lentil. J. Heridity88: 115-119. Sudupak MA. 2004. Inter-and intraspecies inter simple sequence repeat (ISSR) variation in the genus Cicer. Euphytica 135: 229-238.

Talebi R, Fayaz F, Mardi M, Pirsyedi SM and Naji AM. 2008. Genetic Relationships among Chickpea (Cicer arietinum) Elite Lines Based on RAPD and Agronomic Markers. Int. J.Agri. Biol. 10: 301-305.

Tayyar RI and Waines JG. 1996. Genetic relationships among annual species of Cicer (Fabaceae) using isozyme variation. Theor. Appl. Genet. 92: 245254.

\section{How to cite this article:}

Sarnobat, D.H., C.D. Deokar and Raghuwanshi, K.S. 2019. Determination of Genetic Relationship among Wilt Resistant and Susceptible Varieties of Chickpea by RAPD Markers. Int.J.Curr.Microbiol.App.Sci. 8(02): 906-914. doi: https://doi.org/10.20546/ijcmas.2019.802.103 